Omni-Akuatika, 14 (2): 107 - 115, 2018
ISSN: 1858-3873 print / 2476-9347 online
Research Article
journal homepage: http://ojs.omniaquatika.net

\title{
Transfer of Green Fluorescent Protein (GFP) Gene to Betta splendens Embryos by Transfection and Electroporation Methods
}

\author{
Eni Kusrini ${ }^{1{ }^{*}}$, Alimuddin ${ }^{2}$, Erma Primanita Hayuningtyas ${ }^{1}$, Syuhada Restu Danupratama ${ }^{2}$ \\ ${ }^{1^{*}}$ Research Institute for Ornamental Fish Culture, Depok, Indonesia \\ ${ }^{2}$ Department of Aquaculture, Faculty of Fisheries and Marine Science, Bogor Agricultural University, \\ Bogor 16680, Indonesia
}

${ }^{*}$ Corresponding author : enikusrini1309@gmail.com

\begin{abstract}
Transfection and electroporation method shave a high possibility to apply towards transgenic production of small eggs size fish species. This study aimed to examine the potential of transfection and electroporation methods to use for transferring a foreign gene into betta fish (Betta splendens) embryos using green fluorescent protein (GFP) gene as a model. Fish were spawned naturally in the ratio of male: female was $1: 1$, then a total of 200 eggs were taken for each treatment. Transfection was performed for 30 minutes (room temperature of about $25^{\circ} \mathrm{C}$ ) at twocell stage of embryos using transfast reagent. Transfection reaction consisted of $0.75 \mu \mathrm{L}$ transfast reagent, $0.25 \mu \mathrm{L}$ GFP expression vector (DNA concentration: $50 \mu \mathrm{g} / \mu \mathrm{L}$ ) and $99 \mu \mathrm{L} \mathrm{NaCl}$ solution (concentration: 0,95\%). Electroporation was performed using 125 volt $\mathrm{cm}^{-1}, 3$ times pulse frequency at one second interval and pulse length of 7 micro seconds. A volume of $800 \mu \mathrm{L}$ GFP expression vector solution (DNA concentration: $50 \mu \mathrm{g} / \mu \mathrm{L}$ ) in PBS was used for electroporation. The successful of foreign gene transfer was determined by PCR method with GFP specific primers. The results showed that hatching rate of eggs in transfection treatment was $67.08 \%$, while the electroporation was $72.09 \%$. Survival of larvae in transfection treatment was $73.00 \%$, while the electroporation was $75.00 \%$. The results of PCR analysis showed that transfection method allowed $65 \%$ of the survived fish carrying GFP gene, whereas the electroporation method was $70 \%$. Thus, foreign gene transfer in betta fish can be conducted using the transfection and electroporation methods.
\end{abstract}

Keywords: electroporation, embryo, gene transfer, transfection, Betta splendens

\section{Introduction}

Betta fish (Betta splendens) is a freshwater ornamental fish widely known in Indonesia. Betta fish is popular in Indonesia as fighting fish and ornamental fish. Ornamental betta fish is commonly preferred by people for its beautiful color in the body and fins. Betta fish strain has very much variation based on color and shape of fin.

Beautiful color in betta fish can be obtained through selection, but this method takes quite a long time (5-7 generation). Selection method is generally performed by betta fish culturists, thus various types of betta fish are widely available. A more modern method yet rarely applied in ornamental fish is transgenesis (gene transfer). Application of transgenesis is expected to improve desirable characteristics for aquaculture such as growth rate increase, muscle quality improvement, as well as increase in fish resistance to extreme environment and diseases (Parenrengi et al., 2011). In ornamental fish the character improvement is intended for color and shape.

Transgenesis is applied to introduce new genetic characteristics or over-expression to individual throughthe introduction of foreign gene connected to the host genome, which is expected to be inherited to the offspring through gonad cell (Yoshizaki 2001). The main principle of this technic is to insert foreign DNA to the nucleus of a target cell and combine it to the host genome (Hidayani et al., 2011). 
Several transgenesis methods include microinjection, electroporation, transfer through sperm, biolistic, the use of viral vector, lipofection, and transfection (Harrison et al., 1998; Beaumont \& Hoare 2003).

Transfection is a method of gene transfer based on the use of lipid as an agent to transport foreign gene across cell membrane (Yamano et al., 2011). The advantages of gene transfer through transfection method includes: easy to apply, high implementation success, and not toxic to embryo. Transfection has lower risk of physical damage to target organism, thus hatching rate will increase (Calderon, 2004). Transfection method can be applied for small betta fish egg of $0.8-0.9 \mathrm{~mm}$ in size (Rainwater \& Miller 1967). Hence, transfection method resulted in a relatively higher number of egg applied at certain unit of time (Sun et al., 2005).

Electroporation is a physical process in which electrical field at certain voltage is applied to cell, causing temporary pores on cell membrane. Eventually, cell will be permeable and it is possible for cell to absorb liquid from its surrounding. Electroporation is considered to be the most effective, efficient, and easiest method in gene transfer (Tsai et al., 1997). In fact, this method is able to be applied to many fish eggs simultaneously in a short period of time (Cheng et al., 2002). As a preliminary study in order to modify important characters in betta fish, this research was performed to examine gene transfer success on betta fish embryo using green fluorescent protein (GFP) gene as reporter. This is important, because one of the considerations in transgenesis technology is the selection of the promoter; DNA sequences located in an upstream section genes (Hackett, 1993; Glick \& Pasternak, 2003) that will set the place, time and the expression level of a gene.

The aim of this study was to compare the success of transfection and electroporation methods, and to determine the DNA concentration in GFP gene transfer by electroporation in betta fish embryo (Betta splendens).

\section{Materials and Method}

The design used in this study was Completely Randomized Design with six treatments and three replications of each. Experimental design of GFP gene transfer in betta fish embryo is presented in Table 1 . The use of DNA concentrations based on previous research results on comet fish (Hadie et al., 2010).

Betta fish spawning and egg collection

Ornamental betta fish broodstock were obtained from Research Institute for Ornamental Fish Culture (BRBIH) Depok, West Java.Betta fish of plakat strain were used in this study. Moreover, the broodstocks used were at 5 months of age, healthy and had no morphological defect. The broodstocks selected were measured for their

weight and length. There were six male and 6 female broodstocks used in this research. Male broodstocks were further transferred to spawning containers in the form of plastic basinand spawning substrate of styrofoam previously cut into $7 \mathrm{~cm} \times 5 \mathrm{~cm}$ of size was added. Later, matching process was performed, namely by placing the female broodstock in a plastic glass put inside the spawning containers (Figure 1).

Table1. Experimental design of GFP transfer gene in betta fish embryo

\begin{tabular}{cl}
\hline Treatment & \\
\hline T & Transfection with the addition of DNA and transfast \\
TK & Transfection without DNA and transfast (control) \\
E30 & Electroporation with the addition of PBS and DNA $\left(30 \mu \mu^{-1}\right)$ \\
E50 & Electroporation with the addition of PBS and DNA $\left(50 \mu \mu^{-1}\right)$ \\
EK+ & Electroporation with the addition of PBS and without DNA \\
EK- & Without PBS and DNA \\
\hline Description: & PBS (Phosphate Buffer Saline)
\end{tabular}




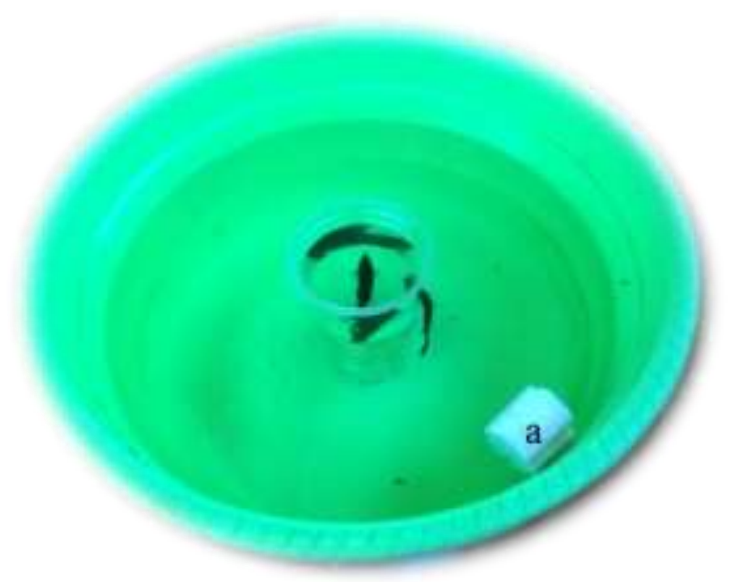

Figure 1. Matching process of Betta fish, (a) spawning substrate in the form of Styrofoam of $7 \mathrm{~cm} x$ $5 \mathrm{~cm}$

Matching activity was done for 1 day. During the process, male fish built bubblenest. After that, female and male fish were placed together in spawning container. Betta fish spawning lasted for $3-4$ hours by natural spawning method.

After spawning process, eggs in the bubblenest were immediately collected and counted. Eggs were placed on petri dish and manually counted using plastic pipette and hand-counter. Number of betta fish eggs used in this study amounted to 200 eggs for each replication of treatment, thus total number of egg used reached 3,600 eggs.

\section{Transfection}

Transfection was performed during embryo phase of 2-64cells. Transfection solution used was a mix of plasmid DNA (concentration of $50 \mu \mathrm{g} \mathrm{mL}^{-1}$ ) and transfast in $0.9 \% \mathrm{NaCl}$ media to reach final volume of 100 $\mu \mathrm{L}$ media. In transfection treatment $(\mathrm{T}), 0.37$ $\mu \mathrm{L}$ of plasmid DNA, $0.75 \mu \mathrm{L}$ of transfast, and $98.89 \mu \mathrm{L}$ of $\mathrm{NaCl}$ were used. Moreover, in control treatment of transfection (TK), there was no addition of plasmid DNA and $0.75 \mu \mathrm{L}$ of transfast, thus $\mathrm{NaCl}$ used was $100 \mu \mathrm{L}$. The solution was further added to the embryo until it was completely sub merged, and later the embryo was incubated at room temperature (approximately $25^{\circ} \mathrm{C}$ ) for 30 minutes. This program referred to the transfection method performed on wild betta fish (Prasetio et al., 2013).

\section{Electroporation}

Electroporation was done by mixing plasmid DNA and phosphate buffer saline (PBS) to reach final volume of $800 \mu \mathrm{L}$. Treatment of E30 plasmid DNA (concentration of $30 \mu \mathrm{g} \mathrm{LL}^{-1}$ ) used $13 \mu \mathrm{L}$ and $787 \mu \mathrm{L}$ of PBS, treatment E50 plasmid DNA (concentration of $50 \mu \mathrm{g} \mathrm{L}^{-1}$ ) used $22 \mu \mathrm{L}$ and $778 \mu \mathrm{L}$ of PBS, treatment EK+ used $800 \mu \mathrm{L}$ of PBS without the addition of plasmid DNA, and treatment EKwas without the addition of plasmid DNA and PBS. Sample and the mix were put into cuvette which was previously immersed in $95 \%$ ethanol solution and dried. Later, sample was placed in the cuvette. Electroporation was done using Gene Pulserll, and electroporation program was set at voltage of $125 \mathrm{~V} \mathrm{~cm}^{-1}$, pulse frequency of 3 times, pulse length of 7 miliseconds, and interval of 1 second. This program referred to electroporation method performed in pangasius (Dewi et al., 2012) and comet fish (Hadie et al. 2010).

\section{Hatching rate, sampling of weight and length}

After treatments were performed, the number of fertilized eggs were counted. This activity was conducted 1-2 hours after spawning process. Fertilized eggs were transparent, while unfertilized eggs had milk white color. Later, eggs were placed in styrofoam bowl with volume of 1 Land equipped withtea filter. Hatching container of betta fish eggs can be seen in Figure 2 below. 


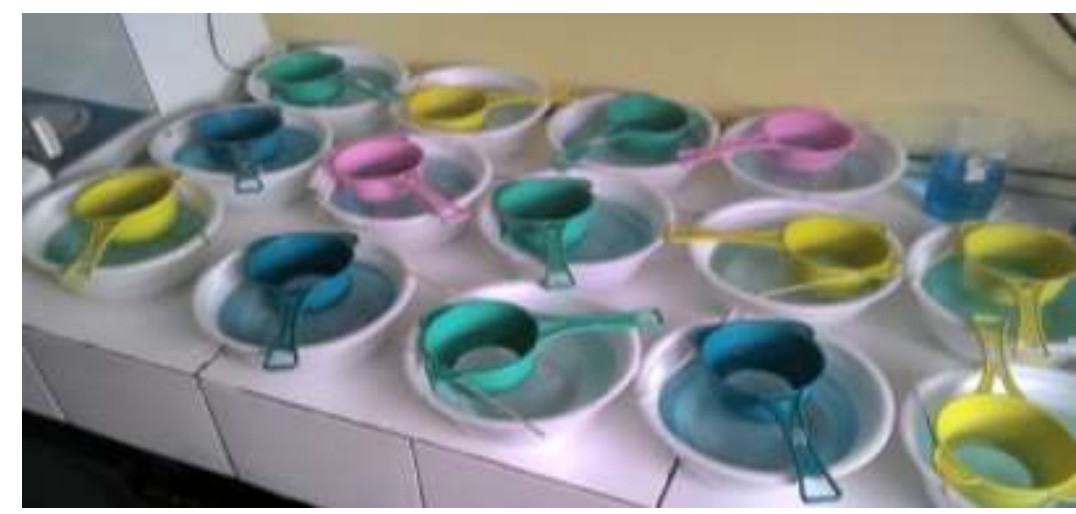

Figure 2. Hatching container of betta fish eggs Betta splendens

Eggs hatched in one to two days later.Hatching rate $(\mathrm{HR})$ was calculated using the formula of Effendie (1997):

$$
H R(\%)=\frac{\text { number of hatched egg }}{\text { number of fertilized egg }} \times 100
$$

Seven days after hatching, larvae were transferred to styrofoam at a size of $40 \mathrm{~cm} \times$ $30 \mathrm{~cm} \times 25 \mathrm{~cm}$. Measurement of fish weight and length was performed once every two weeks. Total number of sample was 30 fish of each treatment or 10 fish of each replication.

Formula of absolute growth in length was calculated according to the formula used by Effendie (1997):

$$
A G L=L_{t}-L_{0}
$$

Description :

AGL : absolute growth in length

$\mathrm{L}_{\mathrm{t}} \quad$ : average fish length at day-t

$L_{0} \quad$ : average fish length at day- 0

(beginning of maintenance)

Formula of growth rate in weight was measured using the formula applied by Effendie (1997):

$$
\mathrm{GR}=\frac{\left(\mathrm{LnW}_{\mathrm{t}}-\mathrm{LnW}_{0}\right.}{\mathrm{t}} \times 100
$$

Description:
DNA extraction and detection of GFP gene

DNA extraction was done through pool sample method with total number of sample amounted to 30 betta fish larvae. DNA was extracted using GeneJET Genomic DNA Purification Kit (Thermo Scientific) followed the method in the manual. Later, measurement of DNA concentration was conducted using Genequant.

Confirmation of GFP gene transfer success into cell was done using PCR method with primers of GFP-F 5'GGTCGAGCTGGACGG- 3' and GFP-R 5'ACGAACTCCAGCAGG- 3' (Rajamuddin, 2010). PCR process was run at predenaturation temperature of $94 \stackrel{\circ}{\circ}$ for 3 minutes: 35 cycles for denaturation of $94{ }^{\circ} \mathrm{Cfor}$ 30 seconds, annealing of 62 다 30 seconds, extension of $72^{\circ} \mathrm{C}$ for 1 minute: and final extension of $72 \stackrel{\circ}{ } \mathrm{C}$ for 3 minutes (Rajamuddin 2010). PCR was performed using PCR machine (Biometra-Jerman).

PCR product was separated through electrophoresis with $1.5 \%$ agarose gel. Agarose gel was putinto electrophoresis container filled with TBE 1x. PCR product was further placed into the wells of agarose gel using micropipette, and DNA marker was inserted as the marker for fragment size of DNA sample. Electrophoresis was performed at voltage of $100 \mathrm{~V}$ for 30 minutes. DNA was visualized using Gel Doc UV Transilluminator. Product of GFP gene amplification was at a size of 600 bp (Rajamuddin, 2010).

\footnotetext{
GR : growth rate in weight

$\mathrm{W}_{\mathrm{t}}$ : average fish weight at day-t

$\mathrm{L}_{0} \quad$ : average fish weight at day-0 (beginning of maintenance)

$\mathrm{t} \quad$ : time of maintenance
} 
As an internal control for gene transfer success, PCR method with primers of $\beta$-actin- $F$ 3'- TTGGTCTGTGC-AGGACAA-3' and $\beta$-actinR 3'-AAGGATCCACTGTAAAAGAAAGGGAA3' (Higashijima et al., 1997). PCR process was run at pre-denaturation temperature of $94{ }^{\circ} \mathrm{C}$ for 3 minutes, 30 cycles for denaturation of $94{ }^{\circ} \mathrm{C}$ for 30 seconds, annealing of $58 \stackrel{\circ}{\circ} \mathrm{C}$ for 30 seconds, extension of $72{ }^{\circ} \mathrm{C}$ for 30 seconds, and final extension of $72{ }^{\circ} \mathrm{C}$ for 3 minutes. PCR was done using PCR machine (BiometraGermany). Product of $\beta$-actingene amplification was at a size around 300 bp (Higashijima et al., 1997). The use of beta actin as an internal control which is house keeping means that the promoter can be active at any time if necessary.

\section{Test parameter and data analysis}

Hatching rate, survival rate, absolute growth in length,andgrowth rate in weight were analyzed using One-wayANOVA and followed with post hoc test of Duncan $(\alpha=0.05)$ using SPSS Statistic 16.0 (IBM, New York, USA).

\section{Results and Discussion}

Analysis result of hatching rate $(\mathrm{HR})$ is presented in Figure 3. Based on the result, there was no significant difference between treatments $(P>0.05)$. Average hatching rate of each treatment was $67.08 \%$; $68.75 \% ; 73.43 \%$; $70.75 \% ; 72.89 \%$; and $73.56 \%$, respectively. Similar finding was also obtained on average hatching rate of wild betta fish Betta imbellis with range of $70 \%-80 \%$ in research using transfection method conducted by Prasetio et al., (2013). Based on the result of One-Way ANOVA on hatching rate, significant value or $P$ value of $0.152(P>0.05)$ was obtained, thus it is concluded that there was no significant difference between hatching rates of each treatment.

This shows that the methods performed both do not significant the hatching rate. The same thing was reported by Tsai et al., (2000) that the hatching rate between the fertilized eggs and electroporation sperm and control sperm is relatively the same. Tsai et al., (2000) also mentions that the difference is only $4 \%$ greater in control sperm.

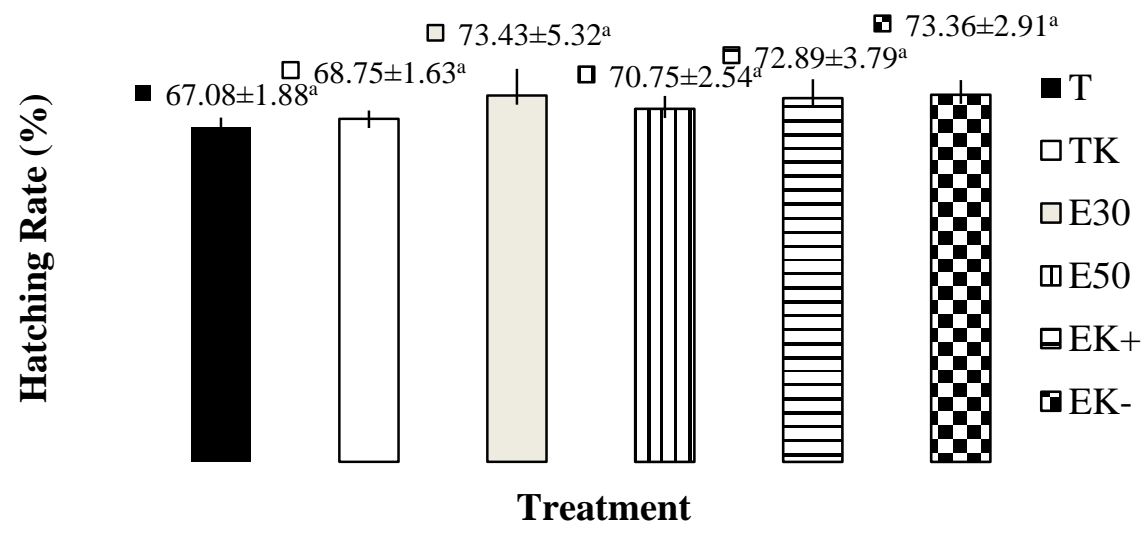

Description: The same superscript letter on the same test parameter showed no significant different result based on post-hoc test of Duncan $(p<0.05)$

Figure 3. Hatching rate of betta fish eggs based on treatment of transfection with the addition of DNA and transfast (T), transfection without DNA and transfast (TK), electroporation with the addition of PBS and DNA at concentration of $30 \mu \mathrm{g} \mathrm{L}^{-1}$ (E30), electroporation with the addition of PBS and DNA at concentration of $50 \mu \mathrm{g}^{-1}$ (E50), electroporation with the addition of PBS and without DNA (EK+), and electroporation without PBS and DNA (EK-) 
Relatively similar to hatching rate was also obtained for larval survival rate. There was no significant difference between the survival value of betta fish larvae at the age of 5 days in both treatments. Result of survival analysis is presented in Figure 4. Result of survival analysis showed that there was no significant different between treatments ( $P>0.05)$. Average survival rate of each treatment was $73.50 \%$; 77.14\%; 72.33\%; 76.67\%; 73.30\%; and $69.68 \%$, respectively. Thus the method of electroporation and transfection carried out with both programs does not affect the survival of the larvae produced.

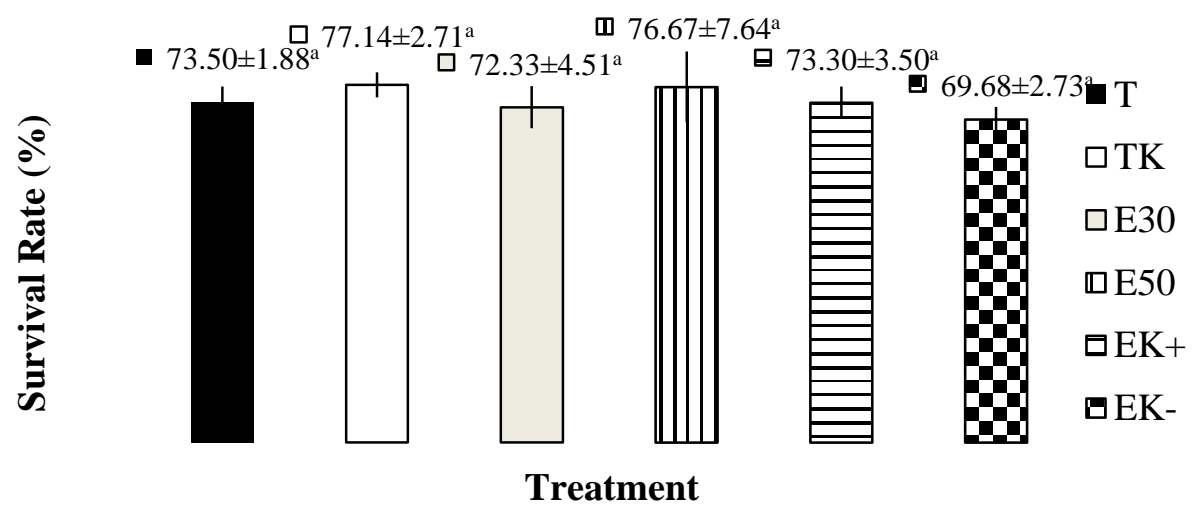

Description: The same superscript letter showed no significant different result based on post-hoc test of Duncan $(p<0.05)$

Figure 4. Survival rate of betta fish based on treatment of transfection with the addition of DNA and transfast $(\mathrm{T})$, transfection without DNA and transfast (TK),electroporation with the addition of PBSand DNA at concentration of $30 \mu \mathrm{gL}^{-1}$ (E30), electroporation with the addition of PBS and DNA at

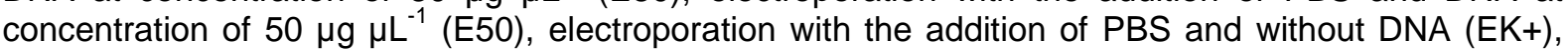
and electroporation without PBS and DNA (EK-)

Detection result of GFP and $\beta$-actinis were presented in Table 2. Descriptively, the values of GFP detected in each treatment were $60.00 \% ; 0.00 \% ; 80.00 \% ; 66.67 \% ; 0.00 \%$;and $0.00 \%$, respectively. Descriptively, $\beta$-actinin all treatments were detected for $100.00 \%$. According to the study result, about $60.00 \%$ of betta fish seed carried the GFP gene after transfection treatment. It indicated that gene transfer through transfection method was able to be applied in betta fish embryo. Similar result was reported in wild bettafish (Prasetio et al., 2013) (Kusrini 2015) that transfection method was able to be used to produce transgenic betta fish. Moreover, electroporation method applied in treatment E30 showed that $80.00 \%$ of the seed carried the GFP gene and in treatment $\mathrm{E} 50$, about $66.67 \%$ of seed carried the GFP gene, which indicated that gene transfer through electroporation method can be applied in the embryo of betta fish Betta splendens. Gene transfer using electroporation method in betta fish has not been scientifically published, yet electroporation with GFP inserted to the eggs through spermatozoa in comet fish can be detected (Hadie et al., 2010) as well as electroporation with GFP gene for transplantation of testicular cell of tilapia (Barades 2014) which showed that the percentage of fluorescent cell ranged of 48.00 $55.33 \%$. 
Table 2. Detection of GFP and $\beta$-actin on transgenic betta fish based on treatment of transfection with the addition of DNA and transfast (T), transfection without DNA and transfast (TK), electroporation with the addition of PBS and DNA at concentration of $30 \mu \mathrm{g} \mu \mathrm{L}^{-1}$ (E30), electroporation with the addition of PBS and DNA at concentration of $50 \mu \mathrm{g} \mathrm{L}^{-1}$ (E50), electroporation with the addition of PBS and without DNA (EK+), and electroporation without PBS and DNA (EK-)

\begin{tabular}{lcc}
\hline \multirow{2}{*}{ Treatment } & \multicolumn{2}{c}{ Parameter } \\
\cline { 2 - 3 } & Detection of GFP $(\%)$ & Detection of $\beta$-actin $(\%)$ \\
\hline TK & $60.00 \pm 0.00$ & $100.00 \pm 0.00$ \\
E30 & $0.00 \pm 0.00$ & $100.00 \pm 0.00$ \\
E50 & $80.00 \pm 20.00$ & $100.00 \pm 0.00$ \\
EK+ & $66.67 \pm 11.55$ & $100.00 \pm 0.00$ \\
EK- & $0.00 \pm 0.00$ & $100.00 \pm 0.00$ \\
\hline
\end{tabular}

Description: The same superscript letter on the same test parameter showed no significant different result based on post-hoc test of Duncan $(\mathrm{p}<0.05)$

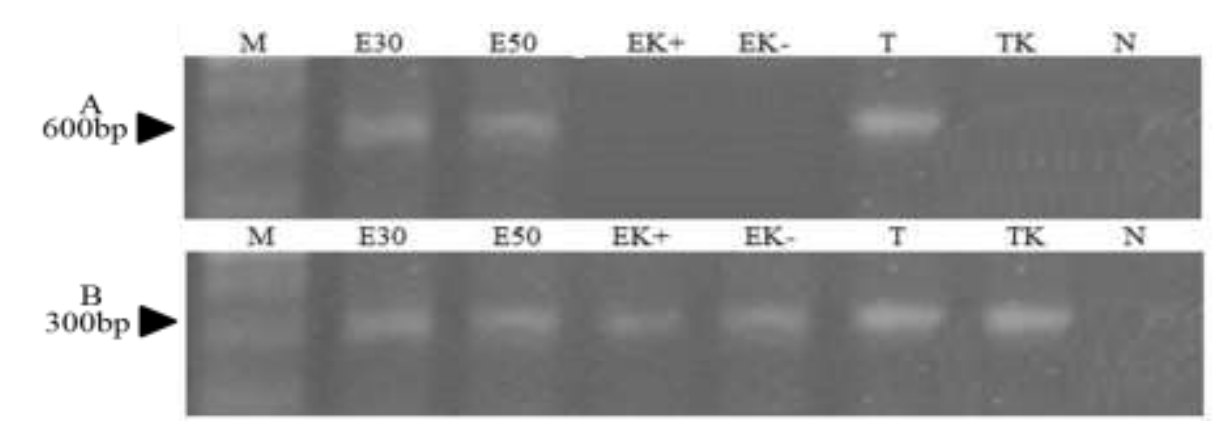

Figure 5. Electroforegram of some samples of PCRproduct using specific primers of GFP (A) and $\beta$ actin (B) with DNA template extracted from caudal fin of betta fish. Marker of DNA fragmentsize (M), electroporation with the addition of PBSand DNA at concentration of $30 \mu \mathrm{g} \mu \mathrm{L}^{-1}(\mathrm{E} 30)$, electroporation with the addition of PBS and DNA at concentration of $50 \mu \mathrm{g} \mu \mathrm{L}^{-1}$ (E50), electroporation with the addition of PBS and without DNA (EK+), electroporation without PBS and DNA (EK-), treatment of transfection with the addition of DNA and transfast $(\mathrm{T})$, transfection without DNA and transfast (TK), and control of PCR $(\mathrm{N})$.

Electroforegram of some samples of PCR-GFP product is shown in Figure 5 . Six samples were not detected in transfection treatment, while all samples of $\beta$-actin were able to be detected. In treatment E30, 3 samples of DNA-GFP were not detected and all samples of $\beta$-actincould be detected, while in treatment $\mathrm{E} 50$, there were 5 samples of DNAGFP that could not be detected yet all samples of $\beta$-actin were detected.

Analysis of GFP detection of pool sample embryo betta fish is positive carrying genes. This suggests that the universal $\beta$-actin promoter used is able to control GFP expression of betta fish. GFP genes transferred in addition to being able to inserted in the body of betta fish are also able to be detected properly. According to Sarmasik
(2003), if the transgenic construction carries a functional promoter, a number of transgenic individuals can be expected to express the transgene. The $\beta$-actin gene in fish is housekeeping gene (can be active whenever needed) and the regulator area is widely used in transgenic fish research.

As a supporting parameter in this study is the growth of larvae. Analysis result of absolute growth in length is seen in Table 3 . Average value of absolute growth in length of each treatment was $1.59 \mathrm{~cm} ; 1.61 \mathrm{~cm}, 1.58 \mathrm{~cm}$; $1.21 \mathrm{~cm} ; 1.55 \mathrm{~cm}$; and $1.54 \mathrm{~cm}$, respectively. Based on the analysis of One-Way ANOVA on absolute growth in length, a value of 0.744 $(P>0.05)$ was obtained. Therefore, it is said that GFP gene did not significantly affect the absolute growth in length of betta fish. 
Table 3. Absolute growth in length (AGL) and growth rate in weight (GR) of betta fish according to treatment, maintained for 90 days post-hatching (hpt)

\begin{tabular}{ccc}
\hline \multirow{2}{*}{ Treatment } & \multicolumn{2}{c}{ Parameter } \\
\cline { 2 - 3 } & AGL $(\mathrm{cm})$ & $\mathrm{GR}\left(\%\right.$. day $\left.^{-1}\right)$ \\
\hline T & $1.59 \pm 0.08^{\mathrm{a}}$ & $5.39 \pm 0.04^{\mathrm{a}}$ \\
TK & $1.61 \pm 0.06^{\mathrm{a}}$ & $5.87 \pm 0.49^{\mathrm{a}}$ \\
E50 & $1.58 \pm 0.40^{\mathrm{a}}$ & $6.04 \pm 0.64^{\mathrm{a}}$ \\
EK+ & $1.21 \pm 0.38^{\mathrm{a}}$ & $5.87 \pm 0.18^{\mathrm{a}}$ \\
EK- & $1.55 \pm 0.21^{\mathrm{a}}$ & $6.33 \pm 0.43^{\mathrm{a}}$ \\
& $1.54 \pm 0.60^{\mathrm{a}}$ & $6.17 \pm 0.80^{\mathrm{a}}$ \\
\hline
\end{tabular}

Description: The same superscript letter on the same test parameter showed no significant different result based on post-hoc test of Duncan $(p<0.05)$

As a supporting parameter in this study is the growth of larvae. Analysis result of growth rate in weight is presented in Tabel 3. Average growth rate in weight of each treatment was $5.39 \%$ day $^{-1} ; 5.53 \%$ day $^{-1} ; 6.04 \%$ day $^{-1} ; 5.86 \%$ day $^{-1} ; 6.33 \%$ day ${ }^{-1}$; and $6.16 \%$ day ${ }^{-1}$, respectively. Based on One-Way ANOVA, the growth rate in weight was $0.326 \quad(P>0.05)$. Therefore, it is said that GFP gene did not affect the growth rate in weight of betta fish.

\section{Conclusion}

The method of transfection and electroporation was successfully used in GFP gene transferin betta fish embryo. DNA concentration in GFP gene transfer by electroporation in betta fish embryo was $30 \mu \mathrm{g}$ $\mu \mathrm{L}^{-1}$.

\section{References}

Barades, E., Alimuddin., A.O. Sudradjat. 2014. Electroporation and transplantation of testicular cells with GFP label on tilapia. Jurnal Akuakultur Indonesia 12 (2), 186192 (2013).

Beaumont, A.R., Hoare, K. 2003. Biotechnology and Genetics in Fisheries and Aquaculture. Oxford: Blackwell Science Ltd. 158pp.

Harrison, R.L, Byrne B.J, Tung L. 1998. Electroporation-mediated gene transfer in cardiac tissue. FEBS etters.435(1):15.

Hidayani, A.A., O. Carman., Alimuddin. 2011. The effectivity of promoter $\beta$-actin in directing the expression of target genes in goldfish transgenesis. Jurnal Akuakultur Indonesia 10 (1),16-23.
Calderon FRO. 2004. Transfection reagentmediated gene transfer for the pacific white shrimp Litopenaeus vannamei [thesis]. Hawaii: University of Hawaii.

Cheng CA, Lu KL, Lau EL, Yang TY, Lee CY, Wu JL, Chang CY. 2002. Growth promotion in ayu Plecoglossus altivelis by gene transfer of the rainbow trout growth hormone gene. Zoological Studies.41(3): 303-310.

Dewi RRSPS, Alimuddin, Sudrajat AO, Sumantadinata K. 2012. The effectivity of PhGl almus). Jurnal Riset Akuakultur, 7(2): 171-180.

Effendie MI. 1997. Biologi Perikanan. Yogyakarta (ID): Yayasan Pustaka Nusatama. 163pp.

Glick BR \& Pasternak JJ. 2003. Molecular Biotechnology : Principles and Applications of Recombinant DNA. Third ed. ASM Press. Washington DC.

Hackett PB. 1993. The Molecular Biology of Transgenic Fish. In: Hocachka and Mommesen (Eds.). Biochemistry and Molecular Biology of Fishes 2 : 218-221.

Hadie W, Kusrini E, Priyadi A, Alimuddin. 2010. Insertion of color genes in carassius auratus fish using electrophoration method in an effort to improve the quality of ornamental fish. Jurnal Riset Akuakultur. 5(3):335-343.

Higashijima, S., Okamoto, H., Ueno, N., Hotta Y., Eguchi, G. 1997. High frequency generation of transgenic zebrafish which 
reliably express GFP in whole muscles or the whole body by using promoters of zebrafish origin. Dev Biol. 192(2):289299.

Kusrini, E. 2015. Transfection is a transgenic technology method of insertion of green fluorescent protein to wild betta fish. Media Akuakultur. 10(1):7-11.

Parenrengi, A., A. Tenriuo., S. Tonnek., S. Lante. 2011. Transfer of antiviral gene with different DNA concentrations to tiger shrimp (Penaeus monodon) embryo. Journal Riset Akuakultur, 6(3): 353-361.

Prasetio, A.B., Kusrini, E., Kusumah, R.V., Cindelaras, S., Murniasih S. 2013. The effectivity of transfection methods in gene transfer in the zigot of betta fish (wild betta), Betta imbellis. Jurnal Riset Akuakultur.8(2):191-199.

Rainwater, F.L., Miller, R.J. 1967. Courtship and reproductive behavior of the

Sarmasik, A. 2003. Application of gene transfer technology for genetic improvement of fish. Turk J Zool 27: 1-6.

Sun, P.S., Venzon, J.r. N.C., Calderon, F.R.O., Esaki, D.M. 2005. Evaluation of methods for DNA delivery into shrimp zygotes of Penaeus (Litopenaeus) vannamei. Aquaculture.243: 19-26.

Tsai, H.J., Lai, C.H., Yang, H.S. 1997. Sperm as carrier to introduce an exogenous DNA fragment into the oocyte of Japanesse abalone Haliotis deversicolor supertexta. Transgenic Research.6(14):85-95.

Tsai, H.J. 2000. Electroporated sperm mediation of gene tranfer system for finfish and shellfish. Mol Repro Dev 56: 281-284.

Yamano, S., Dai, J., Yuvienco, C., Khapli, S., Moursi, A.M., Montclare, J.K. 2011. Modified Tat peptide with cationic lipid enhances gene transfection efficiency via temperature-dependent and caveolae-mediated endocytosis. Jurnal of Controlled Release.152 (2) : 278-285.

Yoshizaki G. 2001. Gene transfer in salmonidae: applications to aquaculture. Suisan zoshuku. 49(2):137-142.
Siamese fighting fish Betta splendens Regan (Pisces, Belontiidae). Proceedings of the Oklahoma Academy of Science. 47:98-114.

Rajamuddin, M.A.L. 2010. Introduction and expression of GFP gene (green fluorescent protein) by different promoters on somatic embryos of seaweed Kappaphycus alvarezii. [thesis]. Bogor (ID): Bogor Agricultural University. 